\title{
Reklamlarda İşlenen Kültü̈rel Kodlar Karşısında Türk ve Alman Halklarının Gösterdikleri Tepkinin Ölçülmesine Yönelik Uygulamalı Bir Çalışma: “Axe: Erkekler De Ăglar” Reklamı Örneklemi
}

\author{
A Practical Study to Measure the Response of Turkish and German Peoples to \\ Cultural Codes in Advertisements: "Axe: Men Also Cry" Advertisement Sample
}

\author{
Sedat ŞIMŞEK* \\ Tuana AYAYDINLI** \\ Osman $A D A Y^{* * *}$ \\ Deniz KURTYILMAZ ${ }^{* * * *}$
}

\begin{abstract}
$\ddot{O} Z$
Talep yaratma sanatı olarak tanımlanan reklam, çă̆ımızın en önemli ticari enstrümanlarından biridir. Özellikle uluslararası firmalar ürün satışlarını arttırabilmek için çeşitli pazarlama stratejileri geliştirmekte ve reklamlarında kültürel ögelere gönderme yapmaktadırlar. Bazen kültürel kodları olduğu gibi kullanan reklamlar, bazen de bu kodları sorgulatan temalar barındırmaktadırlar. Bu çalışma, toplumsal cinsiyet kalıplarını sorgulayan "Axe: Erkekler De A ğlar”, reklam çalışmasını incelemektedir. Can Bonomo tarafindan seslendirilen bir şarkı eşliğinde ăglayan erkekleri gördügümüz reklamın farklı kültürler tarafindan nasıl algılandı̆̆ çalışmamızın konusunu oluşturmaktadır. Çalışmamızda, Türkiye'de ve Almanya'da üniversite eğitimi gören katılımcılardan oluşan gruplara üç soruluk bir anket çalışması uygulanmış ve toplumsal cinsiyetle ilgi farkındalıkları ölçülmüştür. Ardından her iki gruba da Axe reklamı izletilip on soruluk bir anket çalışması daha uygulanmıştır. Böylece reklamda farklı kültür mensuplarının reklamlarda kullanılan kültürel kodlara nasıl tepki verdiği ortaya konduğu gibi reklamın bu konuda ne derece etkili olduğu ortaya çıkarılmıştır. Çalışmamız, Türk ve Alman katılımcılar arasında toplumsal cinsiyet konusunda büyük bir anlayış farkının olmadı̆̆ı sonucuna ulaşmıştır.
\end{abstract}

ANAHTAR KELIMELER

Anahtar Kelimeler: Reklam, Kültür, Toplumsal Cinsiyet, Kültürel Kodlar

\begin{abstract}
Defined as the art of creating demand, advertising is one of the most important commercial instruments of our time. In particular, international companies develop various marketing strategies in order to increase product sales and refer to cultural elements in their advertisements. Sometimes ads that use cultural codes as they are, also contain themes that question these codes. This study examines the "Axe: Men Also Cry" advertisement that questions gender patterns. The subject of our study is how the advertisement that we see the men crying with a song performed by Can Bonomo is perceived by different cultures. In our study, the group of participants receiving university education in Turkey and in Germany, applied to a three-question survey and gender-awareness and interest are measured. Then, both groups were watched as Axe advertisement and a ten-question questionnaire was applied. In this way, how the members of different cultures react to the cultural codes used in advertising, and how effective the advertising is, has been revealed. Our study concluded that there was no significant difference in understanding between the Turkish and German participants on gender issues.
\end{abstract}

KEYWORDS

Keywords: Advertisement, Culture, Gender, Cultural Codes

\begin{tabular}{|c|c|c|}
\hline \multicolumn{2}{|r|}{$\begin{array}{c}\text { Makale Geliş Tarihi / Submission Date } \\
06.09 .2019\end{array}$} & $\begin{array}{c}\text { Makale Kabul Tarihi / Date of Acceptance } \\
\text { 31.10.2019 }\end{array}$ \\
\hline Atıf & $\begin{array}{l}\text { Şimşek, S., Ayaydınlı, T., Aday, O. ve } \\
\text { ve Alman Halklarının Gösterdikleri } \\
\text { Ağlar” Reklamı Örneklemi. Selçuk } \ddot{U} n\end{array}$ & $\begin{array}{l}\text { Reklamlarda İşlenen Kültürel Kodlar Karşısında Türk } \\
\text { Yönelik Uygulamalı Bir Çalışma: “Axe: Erkekler De } \\
\text { r Meslek Yüksekokulu Dergisi, } 22 \text { (2), 784-799. }\end{array}$ \\
\hline
\end{tabular}

\footnotetext{
* Prof. Dr., Selçuk Üniversitesi İletişim Fakültesi, ssimsek@selcuk.edu.tr

*** Lisans Öğrencisi, Universität der Künste Berlin Gesellschafts und Wirtschaftskommunikation, tu.ayaydinli5@gmail.com

*** Öğretim Görevlisi, Selçuk Üniversitesi İletişim Fakültesi, osmanaday@gmail.com

**** Araştırma Görevlisi, Selçuk Üniversitesi İletişim Fakültesi, kurtyilmaz@selcuk.edu.tr
} 


\section{GíRiş}

"Acaba kendi irademizle, gerçekten istediğimiz için okuduğumuz, izlediğimiz, dinlediğimiz, giydiğimiz hatta yediğimiz kaç şey kalmıştır?" (Ertike, 2010: 8). Bu sorunun cevabı muhtemelen birçok kişi için çok az şeydir. Çünkü günümüz dünyasında binlerce hatta milyonlarca ürün ve hizmet arasında tercih yaparken insanoğlu birçok faktörün yanı sıra, en başta reklamların etkisinde kalmaktadır. Dünyanın neresinde olursa olsun, reklam hemen herkesin ilgisini çeken ve hedef tüketicinin kulağına, gözüne (Fırlar, 2003: 15), ruhuna seslenerek tercihlerine ve yaşamına etki edebilecek bir iletişim tekniğidir.

Reklamın diğer iletişim tekniklerinden ayrılmasına neden olan en önemli fark, onun açık seçik olması ve reklam olduğunun herkes tarafından biliniyor olmasıdır. Televizyonda ayraçla, gazete de çerçeveyle diğer iletişim süreçlerinden ayrılan (Altunbaş, 2015a: 74) reklam, talep yaratma sanatı olarak tarihe geçmiş bir tanım çerçevesinde eylem gösteren bir faaliyet alanıdır. Ticareti canlandıran, üreticiye yeni satış alanları açan, tüketiciye binlerce ürün arasından kendisine en uygun ürünü bulması anlamında yol gösteren reklam, bütün zamanların en önemli ticari argümanıdır.

Günümüzde vahşi kapitalizmin söz sahibi olduğu ticari faaliyet alanlarında küçük, orta ve büyük ölçekli bütün işletmelerin varlıklarını sürdürebilmek ve rakipleriyle rekabet edebilmek için başvurdukları en önemli silah olan reklam ve reklamcılık sektörü büyük önem taşımaktadır. Dünyanın bir numaralı markaları veya lokal işletmeleri kazançlarının büyük bir bölümünü reklama ayırarak faaliyetlerini sürdürmekte ve bu yolla kâr etmeyi amaçlamaktadırlar. Bu nedenle reklam ve reklamcılık sektörü hızla gelişmekte ve devamlı yükselen bir sektör olarak adından söz ettirmektedir.

Gelişen teknoloji ve sosyal medya ağları sayesinde yeni bir alana evrilen reklamcılık, yalnızca bugünün değil, aynı zamanda geleceğin mesleği olmayı da garantilediği gibi bir numaralı tanıtım ve satış aracı haline gelmiştir. Bu gelişmelere paralel olarak tüm kültür sektörleri gibi edebiyat, sanat, spor, vb. birçok alanda reklam içerikleri gün geçtikçe değişmekte ve artmaktadır (Çamdereli, 2006: 15). Özellikle günümüzde kültürel kodların kullanımı, tüketicinin ilgisini üst seviyede etkilediği için reklam veren ve reklam yapanlar için ürünhizmet satışını arttırmak, bilinirlik katsayısını yükseltmek için başvurulan en önemli yöntemlerden biri olmaktadır.

"Günümüzden binlerce yıl sonra yaşam olup olmayacağı bilinmez ama eğer dünya üzerinde yaşam sürecekse o zamanın insanı da kendisinden öncekileri merak etmekten geri durmayacak ve tıpkı bugünün insanının mağara duvarı resimlerini incelemesi gibi geçmişe dair her şeyi araştırmaya çalışacaktır. İşte o noktada kendisinden önceki insanları, yaşamı, kültürü, ekonomik, toplumsal, siyasal birçok yapıyı tanımasını kolaylaştıran, eline geçirdiği reklam örnekleri olacaktır. Zira Marshall McLuhan'ın da dediği gibi yirminci yüzyılın mağara sanatı reklamdır" (Richards ve Curran'dan akt. Elden ve Bakır, 2010: 9). Geleceğin yıldızı reklam ve bu yıldızları parlatacak olanlar da reklamcılar olacaktır.

\section{KÜLTÜREL KODLAR VE REKLAM İLISSKISİ}

Bir toplumun geçmişine ait bütün değerleri ve geleceğine yönelik yaşama amacı doğrultusunda sahip olduğu özelliklerin tamamı olarak nitelendirilebilecek kültür, toplumları bir arada tutan bir harçtır. Kültür, yaşayan ve yaşatan, var olan ve var olmayı teşvik eden, toplumları birbirinden ayıran ve birbirleri ile tarihi bir köprü kurmasını sağlayan değerler bütünüdür.

Kültürel kodların kullanıldığı birçok reklam günümüz kitle iletişim araçları ve sosyal medya ağlarında boy göstermektedir. Kültürel kodlar söz konusu olduğunda, dünya üzerindeki birçok şirket ve işletme ürün ve hizmetlerinin tanıtımını yapmak ve satışını arttırmak için reklamlarında iki ana strateji izlemektedirler. İlk strateji kültürel farkları bir kenara bırakıp standartlaştırılmış bir reklam mesajı verme yoluna gitmekken, ikinci strateji, pazarlaması yapılan ürün uluslararası olsa bile ürünün pazarlanmak istendiği toplumun kültürel kodlarını reklamlarda kullanmaktır. İlk strateji maliyet açısından cazip olsa da yeterli olmayabilir. Bu yüzden reklam verenler ve reklamlar kültürel değerleri hesaba katan bir pazarlama stratejisi izlemenin öneminin farkındadirlar (Gregory ve Munch, 1997: 99).

Reklamı yapılan markanın ürün ve hizmetlerinin rakiplerden ayırabilmek ve tüketicinin zihninde farklı bir yere koyabilmek için kültürel ögelere odaklanılır. Örneğin Amerika'nın kovboyuna (Altunbaş, 2015b: 103), Türkiye'nin İstanbul'una odaklanmak gibi. Özellikle glokal reklam stratejisi çerçevesinde kültürel kodları reklamlarında kullanan şirket ve işletmeler bu sayede amaçlarını (tanıtım ve kâr etme) gerçekleştirmektedirler. Çok uluslu firmaların ürün ve hizmetlerinin tanıtımını yapmak ve satışını arttırmak için bulundukları ülkelerin kültürel kodlarını reklamlarda kullanmaları stratejilerine gönderme yapan glokal reklam stratejisi bu anlamda büyük önem taşımaktadır. 


\subsection{Türk Kültür İmgeleri ve Toplumsal Cinsiyet}

Sağlam ve büyük bir aile, vatan sevgisi, askerlik, baklava, Türk kahvesi, Türk misafirperverliği, cami, Ramazan ayı ve oruç ibadeti, vakur aile babası ya da cefakâr anne gibi (Şimşek, 2006: 110-121) bazı kalıpları barındıran ve geçmişi yüzyıllara dayanan Türk kültür imgeleri, Türk halkı ve yaşamı için büyük önem taşımaktadır. Türk toplumuna dair kolektif bir bilinç oluşturan ve aynı yolla sosyal yapıyı bir arada tutan bu kültür imgelerinin, satış ve tanıtım alanındaki etkisini fark eden yabancı ve yerli birçok şirket ürün ve hizmet tanıtımında bu imgeleri yoğun bir şekilde kullanmaktadırlar.

Örneğin, Osmanlı tarihine bakıldığında, bir kültür imgesi olarak değerlendirilebilecek padişahlık mührü o zamanın reklamların üstünde kullanılmıştır. Bunun nedeni devletin en üst makamı olan padişahın, reklamda adı geçen ürüne onay verdiğinin gösterilmek istenmesidir. Bununla birlikte Türkiye Cumhuriyeti kurulduktan sonra ise bu uygulamanın yerini Türk geleneksel imgelerinin başında gelen Türk Bayrağının ay ve yıldızı almıştır (Avşar ve Elden, 2005: 27).

Çok ortaklı uluslararası bir firma olan Unilever şirketinin bir ürünü olan Axe firması Johannes Jurgens, James Darcy Lever, Samuel Van Den Bergh, Williem Lever tarafindan kurulmuştur. Unilever firması Axe, Lux, ve Rexona gibi temizlik ya da kişisel bakım ürünlerinden oluşan 400 den fazla markanın sahibidir (kimkurdu.com, 2019). Dünyanın birçok ülkesinde olduğu gibi Türk tüketicilerinin de kullanımına sunulan Axe parfümü markası için Unilever Şirketi, Türk tüketicilerinin dikkatini çekebilmek için "vakur Türk erkeği"nin ağlamaması üzerine kurulan kültürel algısına gönderme yapmıştır. Unilever, "Erkekler de Ağlar" şarkısı üzerine bir reklam stratejisi geliştirmiş ve Türk tüketicilerini etkilemek için bir ironiye imza atmıştır.

Zira kültürel ve toplumsal normlar algımız ve kabullerimiz üzerinde o kadar etkilidir ki cinsiyet bile bu normlardan kurtulamamaktadır. Burada karşımıza "toplumsal cinsiyet" kavramı çıkmaktadır. Cinsiyet, bireyin biyolojik ve fizyolojik olarak sahip olduğu cinsel nitelikleri ifade eden bir kavramdır ve genel olarak insan türünün erkek ve dişi olmak üzere iki ayrı cinsiyetten meydana geldiği kabul edilmektedir (Dumanlı, 2011: 133). Fakat neyin eril, neyin ise dişil kabul edildiği biyolojik/fizyolojik yönelimlerden ziyade büyük ölçüde toplumsal olarak belirlenmektedir. Dolayısıyla "toplumsal cinsiyet kültürel bir kategoridir" ve toplumun erkek ya da kadından beklediği belli kalıp rollerin ne olduğu yansitır (Kalan, 2010: 76).

Her ne kadar son yıllarda bu algıda büyük ölçüde değişim yaşansa da, erkeğin duygusal olarak daha güçlü olduğu ya da duygularını göstermesinin bir zayıflık olarak görüldüğü genel bir kabuldür. Erkek, bir baba olarak güçlü ve sert olmak zorundadır. Türk kültüründe de aynı durum geçerlidir. Kültürümüzde erkek; vakur bir baba olarak, güvenilir, güçlü ve duygularını kolay belli etmeyen bir figür halinde kalıplaştırılmaktadır. Buna karşın kadının da belli kalıplar içinde değerlendirildiği gerçektir. Hatta toplumsal cinsiyetle ilgili kalıpyargıların kadın söz konusu olduğunda daha da baskın olduğu rahatlıkla söylenebilir. Reklamların da bu kalıpları sıklıkla kullandığı görülmektedir. Reklamlara baktığımızda, erkekler genel olarak evin babası rolüyle yer alırken, kadınlar da evin annesi olarak çocukların bakımından ve mutfak işlerinden sorumlu kişiler olarak yansitıldı̆̆ı görülmektedir (Özdemir, 2011: 103).

Son yıllarda cinsiyetlere dair kalıpların yıkılmaya başladığı görülmüşse de reklamların sosyal gelişmelerin gerisinde kalacak şekilde toplumsal cinsiyet kalıplarını sürdürecek anlatılar kullandığı görülmektedir (Knoll vd., 2015: 867). Bununla birlikte, tıpkı çalışmamızda ele alacağımız gibi, zaman zaman bu kalıpları sorgulamaya dönük reklam çalışmalarının da yapıldığ 1 görülmektedir. Çünkü yaşadığımız yüzyılda erkek ya da kadın olmanın ne anlama geldiği çok daha fazla sorgulanır olmaya başlamıştır. Çalışmamız perspektifinden bakıldığında erkeklerin ciddi bir cinsiyet bunalımı yaşadığı, onlardan olması beklenen ve kendi olmak istedikleri insan arasında bir denge kurmaya çalıştıkları açıktır (Gentry ve Harrison, 2010: 75).

Dolayısıyla günümüzde bazı reklamların toplumsal cinsiyete dair sorgulamalar üzerinden bir anlatı geliştirdiği de görülmektedir. Çalışmamızda ele aldığımız reklam da bunlardan biridir. Kişisel bakım ürünleri kullanımının Türk erkeğinin güçlü, sert ve bazen haşin/kaba imajıyla pek örtüşmediği ortadayken, Axe firması öncelikle bu imajı yeniden değerlendirmeye dönük bir reklam stratejisi geliştirmeye çalışmaktadır¹.

\footnotetext{
${ }^{1}$ Can Bonomo tarafından seslendirilen reklam şarkısı, özellikle nakarat kısmındaki ezgisiyle, Nilüfer’in 1975 tarihli meşhur şarkısı "Erkekler Ağlamaz” adlı parçasına da bir gönderme yapmaktadır. Nilüfer'in toplumsal cinsiyet kalıbını tekrar eden şarkısının aksine Bonomo'nun yazdığı sözler şu şekildedir: "Her şey kanun, her şey kural, her şey garip/Bıkmadın mı dik durmaktan, gözyaşlarını silip silip?/Sırtında bir yük var, gözün dalıyor/İçindeki çocuk senin yerine ağlıyor... Erkekler de ağlar, sev gözyaşını/Küçükken ağlardın, unuttun mu masum, uslu?/Erkekler de ağlar, katlanamaz hüzne/İndir maskeni bak yaşların, yakışıyor yüzüne... Herkes farklı, herkes renkli, herkes soluk/Güçlü güçsüz herkes ağlar, için için, oluk oluk/Dalmışsın uzaklara, gözlerin donuk/Bekliyor ağlamanı içindeki çocuk... Gözyaşların seni sen yapıyor/Erkekler de ağlar kardeşim silme yaşını.”
} 


\section{TÜRK VE ALMAN HALKLARININ “AXE: ERKEKLER DE AĞLAR” REKLAMI ÜZERINE TEPKILERININ ÖLÇÜLMESINE YÖNELIKK YAPILAN UYGULAMA ÇALIŞMASI}

\section{1.Çalışmanın Konusu}

Bu çalışmanın konusu, toplumsal cinsiyet ve kültürel kodları kendine malzeme edinen "Axe: Erkekler De Ağlar" reklamıdır. Reklamın hem Türk hem de Alman halkı üzerindeki etkisini ölçmek için bir uygulama çalışması yapılmış ve uygulamanın sonuçları alana katkı sağlayabilmek adına aşağıda değerlendirilmiştir.

\section{2.Çalışmanın Amacı}

Reklamın Türk ve Alman toplumları üzerindeki etkilerini ölçmeye yönelik bu çalışma, kültürel kodların reklamlardan önce ve sonra farklı uluslardan insanlar üzerinde nasıl bıraktığı etkiyi ölçmeyi amaçlamaktadır. Ayrıca, kültürel kodların kullanıldığı reklamların ürün tanıtım ve satışını artırmadaki rolünü ortaya çıkarmak bu çalışmanın bir diğer amacını oluşturmaktadır.

\section{3.Çalışmanın Önemi}

Reklamlarda kullanılan kültürel kodların reklama kattığı etkiyi ortaya koymak ve ürün ve hizmet üreten firmaların reklamlarda yeni stratejiler geliştirmelerine öncülük etmek çalışmanın önemini oluşturmaktadır.

\section{4.Çalışmanın Evren ve Örneklemi}

Çalışmanın evrenini Türk ve Alman televizyon izleyicileri, örneklemini ise Türk ve Alman izleyicilerden oluşan belirli sayılardaki örneklem grupları oluşturmaktadır. Örneklem grupları Türkiye ve Almanya'da öğrenimini sürdüren lisans öğrencilerinden meydana gelmektedir.

\section{5.Çalışmanın Yöntemi}

Çalışmada kültürel kodların kullanıldığı reklamların insanlar üzerindeki etkisi ölçmek adına alan çalışması yapılmış ve elde edilen veriler SPSS programı ile analiz edilerek değerlendirilmiştir. Saha araştırması iki aşmadan oluşmaktadır. İlk adımda, Türk ve Alman katılımcılara reklam izletilmeden önce üç soruluk bir anket uygulanmıştır. İkinci adımda ise her iki gruba da reklamın izletilmesinin ardından on soruluk bir anket daha uygulanmıştır. Bu yolla reklamın katılımcıların düşüncelerine ne ölçüde etki edebildiği araştırıldığı gibi, her iki kültür mensuplarının aynı meselelere karşı nasıl bir tutum sergiledikleri ortaya konmuştur.

Çalışmaya katılan grupların demografik özellikleri aşağıdaki gibidir:

Tablo 1. Türkiye'deki katılımcı grubunun yaş ortalaması

\begin{tabular}{|l|l|l|l|l|l|}
\hline & N & Minimum & Maximum & Ortalama & Std. Sapma \\
\hline Yaş & 85 & 17,00 & 27,00 & 21,0706 & 1,92594 \\
Geçerli & 85 & & & & \\
\hline
\end{tabular}

85 üniversite öğrencisinden oluşan Türk katılımcıların en genci 17, en yaşlısı 27 yaşındayken katılımcı grubun yaş ortalaması 21,07 olarak belirleniştir. Yaşa göre dağılım şu şekildedir: 
Tablo 2. Türkiye'deki katılımcı grubunun yaş dağılımı

\begin{tabular}{|c|l|l|l|l|}
\hline & & & & \\
& Sıklık & Oran & Geçerli Oran & Toplam Oran \\
\hline Yaş 17,00 & 1 & 1,2 & 1,2 & 1,2 \\
18,00 & 11 & 12,9 & 12,9 & 14,1 \\
19,00 & 4 & 4,7 & 4,7 & 18,8 \\
20,00 & 11 & 12,9 & 12,9 & 31,8 \\
21,00 & 22 & 25,9 & 25,9 & 57,6 \\
22,00 & 23 & 27,1 & 27,1 & 84,7 \\
23,00 & 8 & 9,4 & 9,4 & 94,1 \\
24,00 & 2 & 2,4 & 2,4 & 96,5 \\
26,00 & 1 & 1,2 & 1,2 & 97,6 \\
27,00 & 2 & 2,4 & 2,4 & 100,0 \\
Toplam & 85 & 100,0 & 100,0 & \\
\hline
\end{tabular}

Türkiye'deki katılımcı grubunun cinsiyet dağılımı da aşağıdaki tabloda görülmektedir:

Tablo 3. Türkiye'deki katılımcı grubu cinsiyet dağılımı

\begin{tabular}{|l|l|l|l|l|}
\hline & Sıklık & Oran & Geçerli Oran & Toplam Oran \\
\hline Erkek & 27 & 31,8 & 31,8 & 31,8 \\
Kadın & 58 & 68,2 & 68,2 & 100,0 \\
Total & 85 & 100,0 & 100,0 & \\
\hline
\end{tabular}

Buna göre katılımcı grubundaki 27 erkek grubun \%31,8'ini meydana getirirken 58 kadın katılımc1 $\% 68,2$ 'lik oran 1 meydana getirmektedir.

Tablo 4. Almanya'daki katılımeı grubunun yaș ortalaması

\begin{tabular}{|l|l|l|l|l|l|}
\hline & N & Minimum & Maximum & Ortalama & Std. Sapma \\
\hline $\begin{array}{l}\text { Yaş } \\
\text { Geçerli }\end{array}$ & 75 & 18,00 & 35,00 & 24,04 & 1,85337 \\
\hline
\end{tabular}

75 üniversite öğrencisinden oluşan Alman katılımcıların en genci 18, en yaşlısı 35 yaşındayken katılımc1 grubun yaş ortalaması 24,04 olarak belirlenmiştir. Yaşa göre dağılım şu şekildedir: 
Tablo 5. Almanya'daki katılımeı grubunun yaş dağılımı

\begin{tabular}{|l|l|l|l|l|}
\hline Yaş & Sıklık & Oran & Geçerli Oran & Toplam Oran \\
\hline 18,00 & 5 & 6,7 & 6,7 & 6,7 \\
19,00 & 11 & 14,7 & 14,7 & 21,3 \\
20,00 & 27 & 36,0 & 36,0 & 57,3 \\
21,00 & 12 & 16,0 & 16,0 & 73,3 \\
22,00 & 5 & 6,7 & 6,7 & 80,0 \\
23,00 & 1 & 1,3 & 1,3 & 81,3 \\
24,00 & 3 & 4,0 & 4,0 & 85,3 \\
25,00 & 4 & 5,3 & 5,3 & 90,7 \\
26,00 & 1 & 1,3 & 1,3 & 92,0 \\
28,00 & 4 & 5,3 & 5,3 & 97,3 \\
29,00 & 1 & 1,3 & 1,3 & 98,7 \\
35,00 & 1 & 1,3 & 1,3 & 100,0 \\
Total & 75 & 100,0 & 100,0 & \\
\hline
\end{tabular}

Almanya'daki katılımcı grubunun cinsiyet dağılımı aşağıdaki tabloda görülmektedir:

Tablo 6. Almanya'daki katılımeı grubu cinsiyet dağılımı

\begin{tabular}{|r|l|l|l|l|}
\hline & & & & \\
& Frequency & Percent & Valid Percent & Cumulative Percent \\
\hline Valid Erkek & 21 & 28,0 & 28,0 & 28,0 \\
Kadın & 54 & 72,0 & 72,0 & 100,0 \\
Total & 75 & 100,0 & 100,0 & \\
\hline
\end{tabular}

Tabloya göre katılımcı grubundaki 21 erkek grubun \%28'ini meydana getirirken 54 kadın katılımc1 \%72'lik bir oranı oluşturmaktadırlar.

Çalışmada, Axe reklamının izlenmesinden önce 3 soruluk bir anket çalışması ayrı ayrı olacak şekilde Türk ve Alman katılımcılarla uygulanmış ve şu yanıtlar alınmıştır: 
Tablo 7. Sizce televizyon kanallarında gösterilen reklamlarda, stereotipik kadın ve erkek rolleri kullanılıyor mu?

\begin{tabular}{|c|c|c|c|c|c|}
\hline & & & $\begin{array}{l}\text { Sizce televizyc } \\
\text { gösterilen reklam } \\
\text { kadın ve erkek rolle }\end{array}$ & $\begin{array}{l}\text { knallarında } \\
\text { larda, stereotipik } \\
\text { ri kullanılıyor mu? }\end{array}$ & \\
\hline & & & $\begin{array}{l}\text { Hayır, bence } \\
\text { kullanılmıyor. }\end{array}$ & $\begin{array}{l}\text { Evet, reklamlarda } \\
\text { kadınlara } \\
\text { erkeklere } \\
\text { stereotipik } \\
\text { veriliyor. }\end{array}$ & Toplam \\
\hline & Türkiye & Verilen cevap sayısı & 19 & 66 & 85 \\
\hline & & Oran & $22,4 \%$ & $77,6 \%$ & $100,0 \%$ \\
\hline & & Toplam içindeki oran & $73,1 \%$ & $49,3 \%$ & $53,1 \%$ \\
\hline & Almanya & Verilen cevap sayısı & 7 & 68 & 75 \\
\hline & & Oran & $9,3 \%$ & $90,7 \%$ & $100,0 \%$ \\
\hline & & Toplam içindeki oran & $26,9 \%$ & $50,7 \%$ & $46,9 \%$ \\
\hline Toplam & & Verilen cevap sayısı & 26 & 134 & 160 \\
\hline & & Oran & $16,3 \%$ & $83,8 \%$ & $100,0 \%$ \\
\hline & & & $100,0 \%$ & $100,0 \%$ & $100,0 \%$ \\
\hline
\end{tabular}

Reklam öncesi değerlendirme anketinin "Sizce televizyon kanallarında gösterilen reklamlarda, stereotipik kadın ve erkek rolleri kullanılıyor mu?” sorusuna verilen cevaplara bakıldığında görülmektedir ki Türkiye’deki katılımcıların \%77,6's1 reklamlarda cinsiyetlere stereotipik roller verildiğini düşünmektedir. Bu oran Almanya' daki katılımcılarda çok daha yüksek biçimde \%90,7 olmuştur.

Tablo 8. Toplumsal meseleleri reklamda görmek, size bu toplumsal meseleleri düşündürüyor mu?

\begin{tabular}{|c|c|c|c|c|c|}
\hline & & & \multicolumn{3}{|c|}{$\begin{array}{l}\text { Toplumsal meseleleri reklamda görmek, size bu } \\
\text { toplumsal meseleleri düşündürüyor mu? }\end{array}$} \\
\hline & & & Hayır, hiç. & $\begin{array}{l}\text { Evet, } \\
\text { düşündürüyor. }\end{array}$ & Fark etmedim. \\
\hline \multirow[t]{6}{*}{ Ülke } & Türkiye & Verilen cevap sayısı & 3 & 73 & 9 \\
\hline & & Oran & $3,5 \%$ & $85,9 \%$ & $10,6 \%$ \\
\hline & & Toplam içindeki oran & $25,0 \%$ & $56,6 \%$ & $47,4 \%$ \\
\hline & Almanya & Verilen cevap sayısı & 9 & 56 & 10 \\
\hline & & Oran & $12,0 \%$ & $74,7 \%$ & $13,3 \%$ \\
\hline & & Toplam içindeki oran & $75,0 \%$ & $43,4 \%$ & $52,6 \%$ \\
\hline \multirow[t]{3}{*}{ Toplam } & & Verilen cevap sayısı & 12 & 129 & 19 \\
\hline & & Oran & $7,5 \%$ & $80,6 \%$ & $11,9 \%$ \\
\hline & & & $100,0 \%$ & $100,0 \%$ & $100,0 \%$ \\
\hline
\end{tabular}

Reklam öncesi değerlendirme anketinin "Toplumsal meseleleri reklamda görmek, size bu toplumsal meseleleri düşündürüyor mu?" sorusuna Türkiye'deki katılımc1lar \%85,9 gibi büyük bir oranda "Evet, düşündürüyor" cevabını vermiştir. Türkiye'deki katılımcıların \%10,6'sı "Fark etmedim" demişken, yalnızca 
\%3,5'i toplumsal meseleleri reklamlarda görmenin onları toplumsal sorunlar hakkında düşünmeye itmediğini söylemiş̧lerdir. Almanya'daki katılımcıların ise \%12'si toplumsal meseleleri reklamlarda görmenin bu sorunlar hakkında düşünmeye sebep olmadığını belirtmiş̧lerdir. "Evet, düşündürüyor" cevabını veren Alman katılımcıların oranı \% 74,7 iken, reklamlardaki toplumsal sorunları fark etmeyenlerin oran $1 \% 13,3$ olmuştur.

Tablo 9. Size reklamlarda gösterilen erkeğin ya da kadının rolü (mesela yemek yapan bir kadın ya da çalışkan ve durumu iyi olan bir erkek) kendi yaşam tarzınızı etkiliyor mu?

\begin{tabular}{|c|c|c|c|c|c|}
\hline & & & \multicolumn{3}{|c|}{$\begin{array}{l}\text { Size reklamlarda gösterilen erkeğin ya da kadının rolü } \\
\text { (mesela yemek yapan bir kadın ya da çalışkan ve durumu } \\
\text { iyi olan bir erkek) kendi yaşam tarzınızı etkiliyor mu? }\end{array}$} \\
\hline & & & $\begin{array}{l}\text { Evet, bence roller } \\
\text { öyle olmalı ve ben } \\
\text { de bu roller içinde } \\
\text { yaşamayı tercih } \\
\text { ediyorum. }\end{array}$ & $\begin{array}{l}\text { Evet, etkiliyor ve } \\
\text { ben öyle } \\
\text { stereotipik } \\
\text { rollerde yaşamayı } \\
\text { istemiyorum. }\end{array}$ & $\begin{array}{l}\text { Hayır, beni } \\
\text { reklamlarda } \\
\text { gösterilen kadın } \\
\text { ve erkek rolleri } \\
\text { etkilemiyor. }\end{array}$ \\
\hline \multirow[t]{6}{*}{ Ülke } & Türkiye & Verilen cevap sayısı & 7 & 28 & 50 \\
\hline & & Oran & $8,2 \%$ & $32,9 \%$ & $58,8 \%$ \\
\hline & & Toplam içindeki oran & $50,0 \%$ & $46,7 \%$ & $58,1 \%$ \\
\hline & Almanya & Verilen cevap sayısı & 7 & 32 & 36 \\
\hline & & Oran & $9,3 \%$ & $42,7 \%$ & $48,0 \%$ \\
\hline & & Toplam içindeki oran & $50,0 \%$ & $53,3 \%$ & $41,9 \%$ \\
\hline \multirow[t]{3}{*}{ Toplam } & & Verilen cevap sayısı & 14 & 60 & 86 \\
\hline & & Oran & $8,8 \%$ & $37,5 \%$ & $53,8 \%$ \\
\hline & & & $100,0 \%$ & $100,0 \%$ & $100,0 \%$ \\
\hline
\end{tabular}

Reklam öncesi değerlendirme anketinin "Size reklamlarda gösterilen erkeğin ya da kadının rolü (mesela yemek yapan bir kadın ya da çalışkan ve durumu iyi olan bir erkek) kendi yaşam tarzınızı etkiliyor mu?" sorusuna Türkiye'deki katılımcıların \%8,2'si stereotipik rollerden etkilendiklerini ve bu tipik roller içinde yaşamak istediklerini belirtmiştir. \%32,9'u rollerden etkilenmekle birlikte bu kalıplaşmış cinsiyet rolleri içinde yaşamak istemediklerini söylemiştir. Türkiye'deki katılımcıların $\% 58,8$ 'i ise reklamlarda gösterilen erkek ve kadın rollerinden etkilenmediğini söylemiştir. Almanya'daki katılımcıların da benzer oranlarda cevap verdiklerini görmek mümkündür. Reklamlardan etkilenen ve bu roller içinde yaşamak isteyen Alman katılımcıların oranı \%9,3'tür. Reklamlardan etkilendiği halde kalıplaşmış cinsiyet rolleri içinde yaşamak isteyemeyen Alman katılımcıların oranı Türkiye'dekilerden \%10 daha fazla olacak şekilde,\%42,7'dir. "Reklamlarda gördüğüm kadın ve erkek rollerinden etkilenmiyorum" cevabını veren Alman katılımcıların oran 1 ise $\% 48$ 'dir.

Reklamın izlenmesinin ardından yapılan 10 soruluk diğer anket çalışmasında sorulan sorular ve alınan yanıtlar ise aşağıdaki gibidir: 
Tablo 10. Bu reklam hakkında ne düșünüyorsunuz?

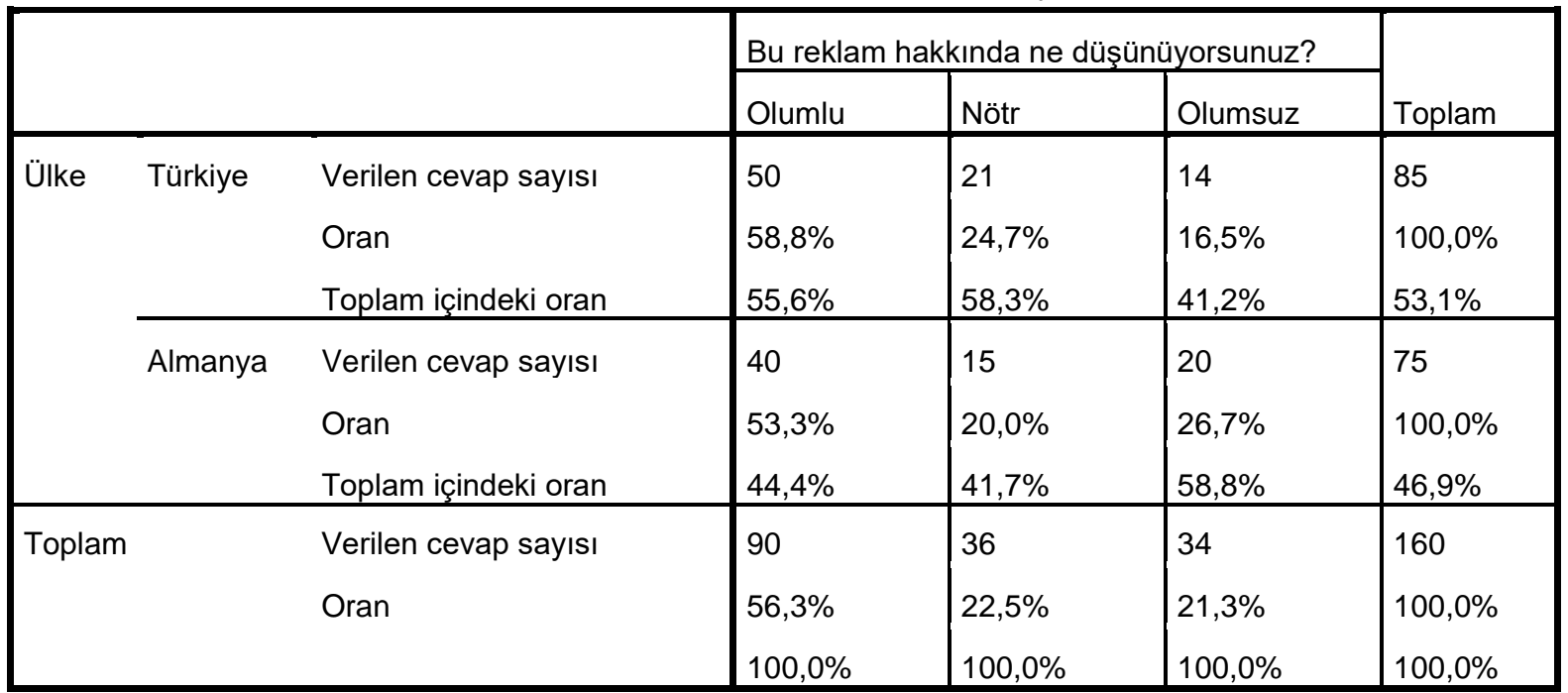

Reklamın izlenmesinin ardından katılımcılara yöneltilen "Bu reklam hakkında ne düşünüyorsunuz?" sorusunun ardından, Türkiye'deki katılımcıların \%58,8'i reklam hakkında olumlu görüş beyan etmiştir. Türkiye'deki katılımcıların \%24,7'si reklama karşı nötr olmuşlarken, \%16,5'i reklam hakkında olumsuz bir kanaate sahiptir. Almanya'daki katılımcıların \%53,3'ü reklam hakkında olumlu bir yaklaşım sergilemişken \%20'si nötr olduklarını ifade etmiştir. Almanya'daki katılımcıların \%26,7'sinin reklama yönelik olumsuz bir tutum sergilemesi ve söz konusu oranın Türkiye'den yüksek çıkması dikkat çekicidir.

Tablo 11. Toplumsal meseleleri reklamda görmek, size bu toplumsal meseleleri düşündürüyor mu?

\begin{tabular}{|c|c|c|c|c|c|}
\hline & & & \multicolumn{3}{|c|}{$\begin{array}{l}\text { Toplumsal meseleleri reklamda görmek, size bu } \\
\text { toplumsal meseleleri düşündürüyor mu? }\end{array}$} \\
\hline & & & Hayır, hiç. & $\begin{array}{l}\text { Evet, } \\
\text { düşündürüyor. }\end{array}$ & Fark etmedim. \\
\hline \multirow[t]{6}{*}{ Ülke } & Türkiye & Verilen cevap sayısı & 5 & 77 & 3 \\
\hline & & Oran & $5,9 \%$ & $90,6 \%$ & $3,5 \%$ \\
\hline & & Toplam içindeki oran & $35,7 \%$ & $56,2 \%$ & $33,3 \%$ \\
\hline & Almanya & Verilen cevap sayısı & 9 & 60 & 6 \\
\hline & & Oran & $12,0 \%$ & $80,0 \%$ & $8,0 \%$ \\
\hline & & Toplam içindeki oran & $64,3 \%$ & $43,8 \%$ & $66,7 \%$ \\
\hline \multirow[t]{3}{*}{ Total } & & Verilen cevap sayısı & 14 & 137 & 9 \\
\hline & & Oran & $8,8 \%$ & $85,6 \%$ & $5,6 \%$ \\
\hline & & & $100,0 \%$ & $100,0 \%$ & $100,0 \%$ \\
\hline
\end{tabular}

Reklamın izlenmesinin ardından yöneltilen "Toplumsal meseleleri reklamda görmek, size bu toplumsal meseleleri düşündürüyor mu?” sorusuna, Türkiye'deki katılımc1lar \%90,5'i gibi yüksek oranda "Evet, düşündürüyor" cevabını vermiştir. Reklamın izlenmesinden önce bu oranın $\% 85,9$ olduğu göz önüne alınırsa, Axe reklamının toplumsal meseleler üzerine düşünmek konusunda pozitif bir etki oluşturduğu söylenebilir. Almanya'daki katılımcıların da \%80'i reklamın izlenmesinin ardından toplumsal meseleleri reklamlarda görmenin onları sosyal problemler üzerinde düşünmeye ittiğini beyan etmişlerdir. Aynı şekilde, izleme öncesi oran Alman katılımcılarda da biraz daha düşük olup \%74,7'dir. Eş deyişle, reklamın sosyal problemler üzerinde düşünme konusunda pozitif etkisi Alman toplumunda da gözlenmiştir. Dikkat çekici bir diğer husus, izleme öncesi ve sonrasında, soruya "Hayır, hiç" cevabını verenlerin oranında büyük bir değişiklik olmamasına karşın "Fark etmedim" cevabını verenlerin oranında görülen değişimdir. Türkiye'deki katılımcılarda 
reklamlardaki toplumsal sorunların varlığını fark etmediğini belirtenlerin oranı, reklamın izlenmesinin ardından \%10,6'dan \%3,5'e düşmüştür. Aynı şekilde Almanya'daki katılımc1larda da oran \% 13,3'ten \%8'e gerilemiştir. Bu bilgi ışığında, Axe reklamının toplumsal bir mesele olan cinsiyet hakkında farkındalık oluşturduğu söylenebilir.

Tablo 12. Sizce televizyon kanallarında gösterilen reklamlarda stereotipik kadın ve erkek rolleri kullanyor mu?

\begin{tabular}{|c|c|c|c|c|c|}
\hline & & & \multicolumn{2}{|c|}{$\begin{array}{l}\text { Sizce televizyon kanallarında } \\
\text { gösterilen reklamlarda stereotipik } \\
\text { kadın ve erkek rolleri kullanıyor mu? }\end{array}$} & \multirow[b]{2}{*}{ Toplam } \\
\hline & & & $\begin{array}{l}\text { Hayır, bence } \\
\text { kullanılmıyor. }\end{array}$ & $\begin{array}{lr}\text { Evet, } & \text { reklamlarda } \\
\text { erkeklere } & \text { ve } \\
\text { kadınlara } & \text { aynı } \\
\text { stereotipik } & \text { roller } \\
\text { veriliyor. } & \\
\end{array}$ & \\
\hline \multirow[t]{6}{*}{ Ülke } & Türkiye & Verilen cevap sayısı & 15 & 70 & 85 \\
\hline & & Oran & $17,6 \%$ & $82,4 \%$ & $100,0 \%$ \\
\hline & & Toplam içindeki oran & $62,5 \%$ & $51,5 \%$ & $53,1 \%$ \\
\hline & Almanya & Verilen cevap sayısı & 9 & 66 & 75 \\
\hline & & Oran & $12,0 \%$ & $88,0 \%$ & $100,0 \%$ \\
\hline & & Toplam içindeki oran & $37,5 \%$ & $48,5 \%$ & $46,9 \%$ \\
\hline \multirow[t]{3}{*}{ Toplam } & & Verilen cevap sayısı & 24 & 136 & 160 \\
\hline & & Oran & $15,0 \%$ & $85,0 \%$ & $100,0 \%$ \\
\hline & & & $100,0 \%$ & $100,0 \%$ & $100,0 \%$ \\
\hline
\end{tabular}

Reklamın izlenmesinin ardından yöneltilen "Sizce televizyon kanallarında gösterilen reklamlarda stereotipik kadın ve erkek rolleri kullanıyor mu?" sorusuna Türkiye'deki katılımcıların \%82,4'ü reklamlarda cinsiyetçi kalıplar kullanıldığı cevabını vermiştir. Reklamın izlenmesinden önce ise bu oran \%77,6 olmuştur. $\mathrm{Bu}$ anlamda, söz konusu reklamın konu hakkındaki düşünceyi değiştirdiği söylenebilir. Almanya'daki katılımcıların \%88 gibi büyük bir oranı reklamlarda cinsiyetlere stereotipik roller verildiğini söylemiştir. Reklam izleme öncesi bu oran Alman katılımcilarda \%90,7’dir. 
Tablo 13. Size reklamlarda gösterilen erkeğin ya da kadının rolü (mesela yemek yapan bir ev kadını ya da çalışkan ve durumu iyi olan bir erkek) kendi yaşam tarzınızı etkiliyor mu?

\begin{tabular}{|c|c|c|c|c|c|}
\hline & & & \multicolumn{3}{|c|}{$\begin{array}{l}\text { Size reklamlarda gösterilen erkeğin ya da kadının rolü } \\
\text { (mesela yemek yapan bir ev kadını ya da çalışkan ve } \\
\text { durumu iyi olan bir erkek) kendi yaşam tarzınızı etkiliyor } \\
\text { mu? }\end{array}$} \\
\hline & & & $\begin{array}{l}\text { Evet, bence roller } \\
\text { öyle olmalı ve } \\
\text { ben de bu rollerin } \\
\text { içinde yaşamayı } \\
\text { tercih ediyorum. }\end{array}$ & $\begin{array}{l}\text { Evet, etkiliyor ve } \\
\text { ben öyle } \\
\text { stereotipik } \\
\text { rollerde } \\
\text { yaşamayı } \\
\text { istemiyorum. }\end{array}$ & $\begin{array}{l}\text { Hayır, beni } \\
\text { reklamlarda } \\
\text { gösterilen kadın } \\
\text { ve erkek rolleri } \\
\text { etkilemiyor. }\end{array}$ \\
\hline \multirow[t]{6}{*}{ Ülke } & Türkiye & Verilen cevap sayısı & 4 & 27 & 54 \\
\hline & & Oran & $4,7 \%$ & $31,8 \%$ & $63,5 \%$ \\
\hline & & Toplam içindeki oran & $36,4 \%$ & $43,5 \%$ & $62,1 \%$ \\
\hline & Almanya & Verilen cevap sayısı & 7 & 35 & 33 \\
\hline & & Oran & $9,3 \%$ & $46,7 \%$ & $44,0 \%$ \\
\hline & & Toplam içindeki oran & $63,6 \%$ & $56,5 \%$ & $37,9 \%$ \\
\hline \multirow[t]{3}{*}{ Toplam } & & Verilen cevap sayısı & 11 & 62 & 87 \\
\hline & & Oran & $6,9 \%$ & $38,8 \%$ & $54,4 \%$ \\
\hline & & & $100,0 \%$ & $100,0 \%$ & $100,0 \%$ \\
\hline
\end{tabular}

Reklam sonrası değerlendirme anketinin "Size reklamlarda gösterilen erkeğin ya da kadının rolü (mesela yemek yapan bir kadın ya da çalışkan ve durumu iyi olan bir erkek) kendi yaşam tarzınızı etkiliyor mu?" sorusuna Türkiye'deki katılımcıların \%4,7'si stereotipik rollerden etkilendiklerini ve bu tipik roller içinde yaşamak istediklerini belirtmiştir. Oysa bu oran reklam öncesi uygulanan ankette daha yüksek şekilde \%8,2'dir. \%31,8'i rollerden etkilenmekle birlikte bu kalıplaşmış cinsiyet rolleri içinde yaşamak istemediklerini söylemiş̧ir. Türkiye'deki katılımcıların \%63,5'i ise reklamlarda gösterilen erkek ve kadın rollerinden etkilenmediğini söylemiştir. Bu oranda da dikkate değer bir değişim yaşanmıştır zira reklam izlenmeden önce bu cevabın oranı \%58,8'dir. Reklamın izlenmesinin ardından Türkiye'deki katılımcıların bir tutum değişikliğine gittiği ifade edilebilir. Almanya'daki katılımcılarda reklamlardan etkilenen ve bu roller içinde yaşamak isteyenlerin oranı izleme öncesinde ve sonrasında aynı kalarak \%9,3 olmuştur. Reklamlardan etkilendiği halde kalıplaşmış cinsiyet rolleri içinde yaşamak isteyemeyen Alman katılımcıların oranı reklam izlendikten sonra da Türkiye'dekinden çok daha yüksek biçimde \%46,7'dir. Reklamın izlenmesinin ardından iki ülke arasındaki fark daha açılarak yaklaşık \%15'e ulaşmıştır. "Reklamlarda gördüğüm kadın ve erkek rollerinden etkilenmiyorum" cevabını veren Alman katılımcıların oranı, reklamın izlenmesinin ardından \%4 düşerek \%44 olmuştur. 
Tablo 14. Bu reklam Türk (Alman) toplumundaki vakur baba imajına zarar verir mi?

\begin{tabular}{|c|c|c|c|c|c|}
\hline & & & $\begin{array}{l}\text { Bu rek } \\
\text { baba im }\end{array}$ & $\begin{array}{l}\text { oplumundaki vakur } \\
\text { verir mi? }\end{array}$ & \\
\hline & & & Evet & Hayır & Toplam \\
\hline Ülke & Türkiye & Verilen cevap sayısı & 17 & 68 & 85 \\
\hline & & Oran & $20,0 \%$ & $80,0 \%$ & $100,0 \%$ \\
\hline & & Toplam içindeki oran & $50,0 \%$ & $54,0 \%$ & $53,1 \%$ \\
\hline & Almanya & Verilen cevap sayısı & 17 & 58 & 75 \\
\hline & & Oran & $22,7 \%$ & $77,3 \%$ & $100,0 \%$ \\
\hline & & Toplam içindeki oran & $50,0 \%$ & $46,0 \%$ & $46,9 \%$ \\
\hline Toplam & & Verilen cevap sayısı & 34 & 126 & 160 \\
\hline & & Oran & $21,3 \%$ & $78,8 \%$ & $100,0 \%$ \\
\hline & & & $100,0 \%$ & $100,0 \%$ & $100,0 \%$ \\
\hline
\end{tabular}

Katılımcılara yöneltilen "Bu reklam Türk (Alman) toplumundaki vakur baba imajına zarar verir mi?" sorusuna, Türkiye'deki katılımcıların \%80'i "Hayır" cevabı verirken \%20'si "Evet" yanıtını vermiştir. Alman katılımcılarda ise bu oran \%77,3'e karşın \%22,7 olmuştur. Her ne kadar aradaki fark çok büyük olmasa da, ağlayan bir baba imajının vakur baba imajına zarar verebileceğini düşünenlerin oranının Alman toplumunda daha yüksek çıkması dikkate değer bir noktadır.

Tablo 15. Az önce izlediğiniz Axe reklamı sizi etkiledi mi?

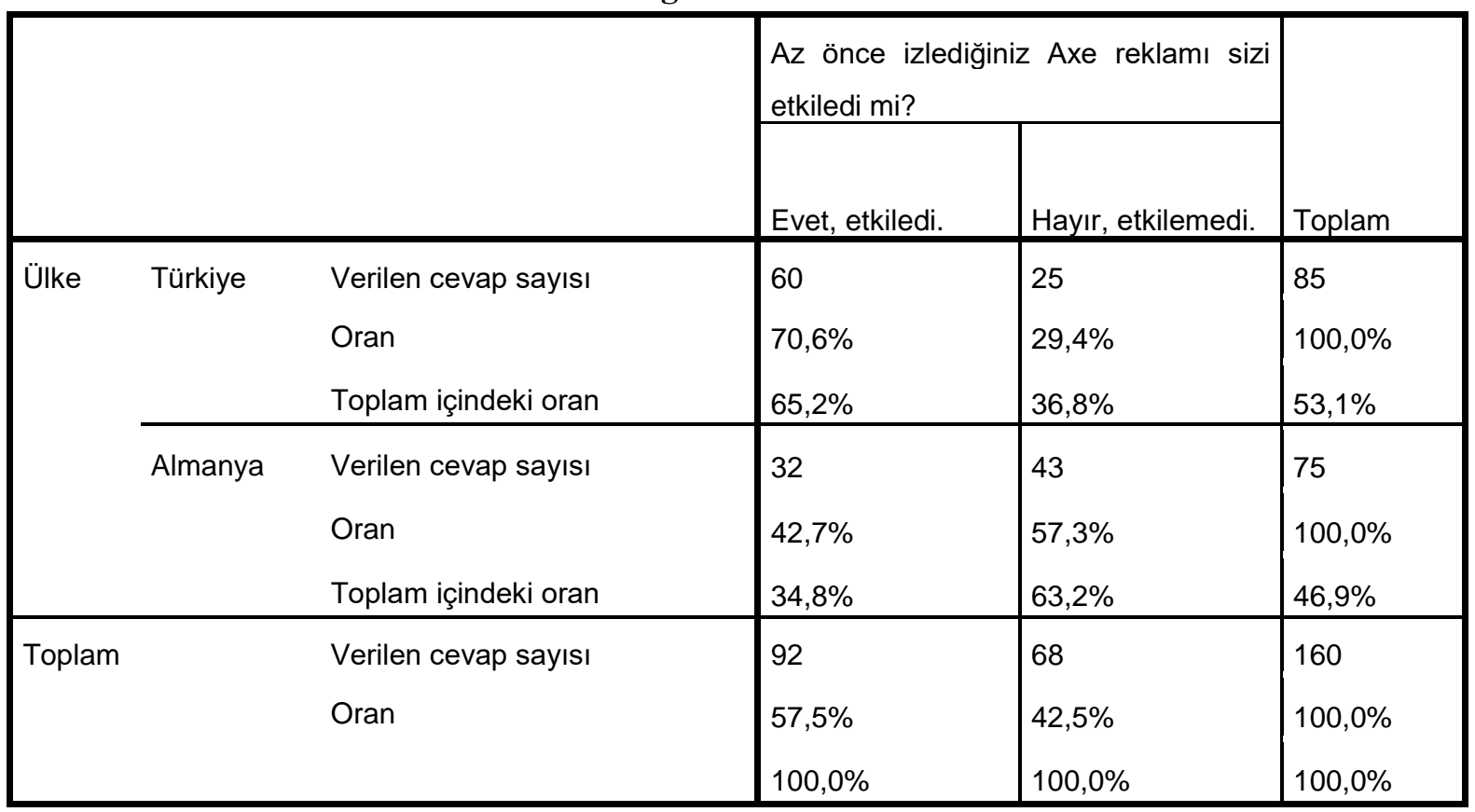

Reklamın izlenmesinin ardından yöneltilen “Az önce izlediğiniz Axe reklamı sizi etkiledi mi?” sorusu iki katılımcı grubu arasında en fazla farkın olduğu soru olmuştur. Bu soruya Türkiye'deki katılımcıların \%29,4'ü "Hayır, etkilemedi" cevabı verirken \% 70,6's1 "Evet, etkiledi” yanıtını vermiştir. Alman katılımcılarda ise söz konusu oran önemli ölçüde değişiklik göstermiş ve katılımcıların yalnızca \%42,7'si "Evet, etkiledi" cevabı verirken \%57,3’ü "Hayır, etkilemedi" demiştir. Reklamın Almanya'daki katılımcılarda tutum değişikliği yaratma etkisi, Türkiye'deki katılımcılara nazaran çok daha düşük olmuştur. 
Tablo 16. Sizce Axe reklamı, erkeklerin toplumdaki rolünü değiştirdi mi?

\begin{tabular}{|c|c|c|c|c|c|}
\hline & & & \multicolumn{3}{|c|}{$\begin{array}{l}\text { Sizce Axe reklamı, erkeklerin toplumdaki rolünü } \\
\text { değiştirdi mi? }\end{array}$} \\
\hline & & & $\begin{array}{l}\text { Evet, daha önce } \\
\text { erkeklere } \\
\text { ağlamanın } \\
\text { yakışmadığını } \\
\text { düşünüyordum. } \\
\end{array}$ & $\begin{array}{l}\text { Hayır, } \\
\text { değiştirmedi ben } \\
\text { zaten herkesin } \\
\text { ağlayabildiğini ve } \\
\text { herkese } \\
\text { yakıştığını } \\
\text { düşünüyorum. } \\
\end{array}$ & $\begin{array}{l}\text { Hayır, } \\
\text { değiştirmedi }\end{array}$ \\
\hline \multirow[t]{6}{*}{ Ülke } & Türkiye & Verilen cevap sayısı & 2 & 71 & 12 \\
\hline & & Oran & $2,4 \%$ & $83,5 \%$ & $14,1 \%$ \\
\hline & & Toplam içindeki oran & $25,0 \%$ & $51,4 \%$ & $85,7 \%$ \\
\hline & Almanya & Verilen cevap sayısı & 6 & 67 & 2 \\
\hline & & Oran & $8,0 \%$ & $89,3 \%$ & $2,7 \%$ \\
\hline & & Toplam içindeki oran & $75,0 \%$ & $48,6 \%$ & $14,3 \%$ \\
\hline \multirow[t]{3}{*}{ Toplam } & & Verilen cevap sayısı & 8 & 138 & 14 \\
\hline & & Oran & $5,0 \%$ & $86,3 \%$ & $8,8 \%$ \\
\hline & & & $100,0 \%$ & $100,0 \%$ & $100,0 \%$ \\
\hline
\end{tabular}

Reklamın izlenmesinin ardından katılımcılara sorulan "Sizce Axe reklamı, erkeklerin toplumdaki rolünü değiştirdi mi?" sorusuna Türkiye'deki katılımcıların \%14'i "Hayır, etkilemedi” cevabı verirken bu oran Alman katılımcılarda yalnızca \%2,7'dir. "Evet, daha önce ağlamanın erkeklere yakışmadığını düşünüyordum" yanıtının oranı Türk katılımcılarda \%2,4 iken Almanlarda \%8 olmuştur. "Hayır, değiştirmedi çünkü ağlamanın herkese yakıştığını düşünüyorum” cevabında ise oranlar Alman katılımcılarda \%89,3 iken Türk katılımcılarda $\% 83,5$ olarak belirlenmiştir.

Tablo 17. Axe'ın reklamı gibi erkeğin ve kadının rolünü tematize eden başka reklamlar biliyor musunuz?

\begin{tabular}{|c|c|c|c|c|c|}
\hline & & & \multicolumn{2}{|c|}{$\begin{array}{l}\text { Axe'ın reklamı gibi erkeğin ve kadının } \\
\text { rolünü tematize eden başka reklamlar } \\
\text { biliyor musunuz? }\end{array}$} & \multirow[b]{2}{*}{ Toplam } \\
\hline & & & Evet, biliyorum. & Hayır, bilmiyorum. & \\
\hline \multirow[t]{6}{*}{ Ülke } & Türkiye & Verilen cevap sayısı & 22 & 63 & 85 \\
\hline & & Oran & $25,9 \%$ & $74,1 \%$ & $100,0 \%$ \\
\hline & & Toplam içindeki oran & $33,3 \%$ & $67,0 \%$ & $53,1 \%$ \\
\hline & Almanya & Verilen cevap sayısı & 44 & 31 & 75 \\
\hline & & Oran & $58,7 \%$ & $41,3 \%$ & $100,0 \%$ \\
\hline & & Toplam içindeki oran & $66,7 \%$ & $33,0 \%$ & $46,9 \%$ \\
\hline \multirow[t]{3}{*}{ Toplam } & & Verilen cevap sayısı & 66 & 94 & 160 \\
\hline & & Oran & $41,3 \%$ & $58,8 \%$ & $100,0 \%$ \\
\hline & & & $100,0 \%$ & $100,0 \%$ & $100,0 \%$ \\
\hline
\end{tabular}


Reklamlarda cinsiyet kalıplarının kullanılmasına dair farkındalığın ölçülmeye çalışıldığı "Axe'ın reklamı gibi erkeğin ve kadının rolünü tematize eden başka reklamlar biliyor musunuz?" sorusu iki katılımcı grup arasında önemli ölçüde fark görebildiğimiz bir diğer soru olmuştur. Almanya'daki katılımcıların \%58,7'si izledikleri Axe reklamından başka, cinsiyet rollerini tematize eden reklamlar bildiklerini ifade etmişlerdir. $\mathrm{Bu}$ oran Türk katılımcılarda yarı yarıya düşerek yalnızca \%25,9' da kalmıştır.

Tablo 18. Bu tür reklamlar, sizce Türk (Alman) halkı için önemli midir?

\begin{tabular}{|c|c|c|c|c|c|}
\hline & & & \multicolumn{2}{|c|}{$\begin{array}{l}\text { Bu tür reklamlar, sizce Türk halkı için } \\
\text { önemli midir? }\end{array}$} & \multirow[b]{2}{*}{ Toplam } \\
\hline & & & Evet & Hayır & \\
\hline \multirow[t]{6}{*}{ Ülke } & Türkiye & Verilen cevap sayısı & 67 & 18 & 85 \\
\hline & & Oran & $78,8 \%$ & $21,2 \%$ & $100,0 \%$ \\
\hline & & Toplam içindeki oran & $53,6 \%$ & $51,4 \%$ & $53,1 \%$ \\
\hline & Almanya & Verilen cevap sayısı & 58 & 17 & 75 \\
\hline & & Oran & $77,3 \%$ & $22,7 \%$ & $100,0 \%$ \\
\hline & & Toplam içindeki oran & $46,4 \%$ & $48,6 \%$ & $46,9 \%$ \\
\hline \multirow[t]{3}{*}{ Toplam } & & Verilen cevap sayısı & 125 & 35 & 160 \\
\hline & & Oran & $78,1 \%$ & $21,9 \%$ & $100,0 \%$ \\
\hline & & & $100,0 \%$ & $100,0 \%$ & \\
\hline
\end{tabular}

Bu tür reklamların kendi toplumlar için önemli olmadığı sorulduğunda her iki katılımcı grubu da büyük çoğunlukla bu tür cinsiyet kalıplarını yıkan reklamların önemli olduğu yanıtını vermiştir. Türkiye'deki katılımcıların \%78,8'i izlediklerine benzer reklamların Türk halkı için önemli olduğunu söylerken bu oran Almanya'daki katılımc1larda \%77,3’tür.

Tablo 19. Ağlayan bir baba figürü, babanıza karşı olan güven duygunuzu zedeler mi?

\begin{tabular}{|c|c|c|c|c|c|}
\hline & & & \multicolumn{2}{|c|}{$\begin{array}{l}\text { Ağlayan bir baba figürü, babanıza karşı } \\
\text { olan güven duygunuzu zedeler mi? }\end{array}$} & \multirow[b]{2}{*}{ Toplam } \\
\hline & & & Evet & Hayır & \\
\hline \multirow[t]{6}{*}{ Ülke } & Türkiye & Verilen cevap sayısı & 2 & 83 & 85 \\
\hline & & Oran & $2,4 \%$ & $97,6 \%$ & $100,0 \%$ \\
\hline & & Toplam içindeki oran & $25,0 \%$ & $54,6 \%$ & $53,1 \%$ \\
\hline & Almanya & Verilen cevap sayısı & 6 & 69 & 75 \\
\hline & & Oran & $8,0 \%$ & $92,0 \%$ & $100,0 \%$ \\
\hline & & Toplam içindeki oran & $75,0 \%$ & $45,4 \%$ & $46,9 \%$ \\
\hline \multirow[t]{3}{*}{ Total } & & Verilen cevap sayısı & 8 & 152 & 160 \\
\hline & & Oran & $5,0 \%$ & $95,0 \%$ & $100,0 \%$ \\
\hline & & & $100,0 \%$ & $100,0 \%$ & $100,0 \%$ \\
\hline
\end{tabular}

Katılımcılara son olarak sorulan "Ağlayan bir baba figürü, babanıza karşı olan güven duygunuzu zedeler mi?” sorusuna Türkiye'deki katılımcıların yalnızca \%2,4’ü "Evet” derken \%97,6 gibi büyük çoğunluğu "Hayır, zedelemez" cevabı vermiștir. Almanya'da ise katılımcıların \%92'si babasını ağlarken görmenin ona karşı duydukları güven duygusuna herhangi bir zarar vermeyeceğini ifade ederken, \%8'i bunun babalarına duydukları güveni zedeleyeceği yanıtını vermiştir. Alman katılımcılarda ağlayan baba figürünün babaya olan 
güven duygusunu zedeleyeceğine dair görüşün Türk katılımcılara nazaran daha yüksek çıkması ilgi çekici bir husustur.

\section{SONUÇ VE ÖNERILER}

Özellikle uluslararası firmalar reklamlarında kültürel ögeleri kullanmak suretiyle glokal reklam stratejisini sürdürebilmektedirler. Aynı şekilde belli bir toplumdaki kültürel değerleri sorgulanması yoluna gitmek de pazarlamada izlenen bir yol olabilir. Elbette böyle bir durumda hassas davranılması zorunluluğu da gündeme gelmektedir çünkü toplumsal ve kültürel değerler çoğunlukla derinlere kök salıp kalıplaşmış yargılar olarak varlıklarını sürdürmektedirler.

Toplumsal cinsiyet de -biyolojik cinsiyetimizden farklı olarak- toplumsal ve kültürel bir değerdir. Kadın ya da erkekten beklenen roller ve davranışlar bir kültürden diğerine farklılık arz etmektedir. Çalışmamızda ele aldığımız “Axe: Erkekler De Ağlar” reklamı, Türkiye'de erkeklik algısının sorgulanması üzerine kurulmuş bir çalışmadır. Bununla birlikte aynı reklamın başka bir kültürde nasıl tepki alacağı sorusu araştırmamızın temel problemini oluşturmuştur.

Reklamın izlenmesinden önce uygulanan üç soruluk anket göstermektedir ki hem Türk hem de Alman katılımcılar reklamlarda cinsiyet kalıplarının kullanıldığının farkındadır ve bu durum her iki katılımcı grubunu da toplumsal cinsiyet meselesi üzerinde düşünmeye sevk etmektedir. Ayrıca, tıpkı reklamlarda gösterildiği gibi kalıplaşmış cinsiyet rolleri içinde yaşamak isteyenlerin oranı her iki toplum içinde de son derece düşüktür. $\mathrm{Bu}$ veriler ışı̆̆ında reklamın izlenmesinden önce bile toplumsal cinsiyete dair bir farkındalığın mevcut olduğu ve her iki katılımcı grubunun da bu türden kalıpyargıları reddetmeye eğilimli olduğu söylenebilir.

Reklamın izlenmesinden sonra uygulanan 10 soruluk anket çalışmasınınsa iki ayrı amacı bulunmaktadır. $\mathrm{Bu}$ amaçlar, Axe reklamının toplumsal cinsiyet kalıpları hakkında ne ölçüde farkındalık yarattığını ölçmek ve ikinci olarak da iki kültür arasında belirgin bir fark olup olmadığını ortaya çıkarmaktır. Öncelikle her iki grubun katılımcıların yarıdan fazlası reklam hakkında olumlu görüş belirtmişlerken; reklamı beğenmeyenlerin oranı her iki grup için ortalama \%21,3 olmuştur. Bu anlamda reklamın başarılı olduğu söylenebilir. Dikkati çeken bir diğer konu reklam hakkında olumlu görüş belirtenlerin oranının Türk katılımcılarda daha yüksek olmasidir.

Diğer yandan, reklamın, toplumsal cinsiyet rolleri hakkında bir farkındalık oluşturmaya yardım ettiği ve izleyicileri bu konu hakkında düşünmeye sevk ettiği açıç̧a görülmektedir. Reklamın izlenmesinin ardından, “Toplumsal meseleleri reklamda görmek, size bu toplumsal meseleleri düşündürüyor mu?" ve "Sizce televizyon kanallarında gösterilen reklamlarda stereotipik kadın ve erkek rolleri kullanıyor mu?" sorularına olumlu cevap verenlerin oranında kayda değer yükselişler yaşanmıştır. İlgili şekilde, hem Türk hem de Alman katılımcılar, cinsiyet kalıplarını sorgulatan bu tür reklamların kendi toplumları için önemli olduğu görüşündedirler. Yine de reklamlarda cinsiyet kalıplarının kullanımı konusunda Alman katılımcıların daha yüksek bir farkındalığa sahip olduğu söylenebilir çünkü "Axe'ın reklamı gibi erkeğin ve kadının rolünü tematize eden başka reklamlar biliyor musunuz?" sorusuna olumlu cevap verenlerin oranı Alman katılımcılarda daha yüksektir.

Dikkat çekici bir diğer husus her iki katılımcı grubunun da ağlayan bir erkek figürünün vakur bir baba imajına zarar vermeyeceğini düşünmesidir. Bununla bağlantılı olarak ağlayan bir babaya karşı güven duygusunun zedelenmeyeceğini söyleyenlerin oranı da oldukça yüksektir. Bu anlamda katılımcıların, toplumsal cinsiyet kalıplarını önemsemedikleri söylenebilir. Zira her iki grubun üyeleri de büyük çoğunlukla reklamın cinsiyet hakkındaki düşüncelerini değiştirmediğini; ağlamanın her insan için doğal bir durum olduğunu belirtmişlerdir.

Sonuç olarak, "Axe: Erkekler De Ağlar" reklamı, toplumsal ve kültürel kalıplar üzerine düşünmeyi kışkırtan başarılı bir çalışmadır. Bununla birlikte alınan cevaplar göstermektedir ki gençler söz konusu kalıpyargıların yanlışlığına dair bir farkındalığa sahiptirler. Diğer yandan, yalnızca üniversite eğitimi gören gençlerle yapılan bu çalışmanın başka demografik özellikler gösteren gruplarla tekrarlanması farklı sonuçların elde edilmesiyle sonuçlanabilir. Bu yüzden alana daha fazla katkı sağlanması adına benzer çalışmaların farklı yaş ya da meslek gruplarıyla da yapılması önerilmektedir. 


\section{KAYNAKÇA}

Altunbaş, Hüseyin, (2015a) Reklamın İyisi Kötüsü Olur, Literatürk Yayınları, Konya.

Altunbaş, Hüseyin, (2015b) Reklam Bize Ters, Literatürk Yayınları, Konya.

Avşar, B. Zakir ve Elden, Müge, (2005) Reklam ve Reklam Mevzuatı, Piramit Yayıncılık, Ankara.

Çamdereli, Mete, (2006) Reklam Arası, Tablet Kitabevi, Konya.

Dumanlı, Duygu, (2011) "Reklamlarda Toplumsal Cinsiyet Kavramı ve Kadın İmgesinin Kullanımı; Bir İçerik Analizi”, Yalova Üniversitesi Sosyal Bilimler Dergisi, 1(2), s. 132-149.

Elden, Müge ve Bakır, Uğur, (2010) Reklam Çekicilikleri, İletişim Yayınları, İstanbul.

Ertike, S. Aybike, (2010) Reklam, Detay Yayıncılık: Ankara.

Fırlar, G. Belma, (2003) Reklam ve Biz, Dokuz Eylül Yayınları, İzmir.

Gregory, D. Garry ve Munch, M. James, (1997) "Cultural Values in International Advertising: An Examination of Familial Norms and Roles in Mexico", Psychology \& Marketing, 14(2), s. 99-119.

Gentry, James ve Harrison, Robert, (2010) "Is Advertising a Barrier to Male Movement Toward Gender Change?", Marketing Theory, 10(1), s. 74-96.

Kalan, G. Özlem, (2010) "Reklamda Çocuğun Toplumsal Cinsiyet Teorisi Bağlamında Konumlandırılışı: 'Kinder' Reklam Filmleri Üzerine Bir İnceleme”, İstanbul Üniversitesi İletişim Fakültesi Dergisi, 1(38), s. 75-89.

Knoll, Silke ve diğ., (2011) "Gender Roles in Advertising: Measuring and Comparing Gender Stereotyping on Public and Private TV Channels in Germany", International Journal of Advertising, 30(5), s. 867-888.

Özdemir, Mehmet, (2010) "Türkiye'deki Reklamlarda Toplumsal Cinsiyet ve Sunumu”, Milli Folklor, 22(88), s. 101 111.

Şimşek, Sedat, (2006), Geleneksel İmgeler ve Reklam, NKM Yayınları, Konya. 